\title{
Low-Frequency Restriction Fragment Analysis of Frankia Strains (Actinomycetales)
}

\author{
MARTHA BEYAZOVA AND MARY P. LECHEVALIER †* \\ Waksman Institute, Rutgers University, Piscataway, New Jersey 08855
}

\begin{abstract}
Low-frequency restriction fragment analysis of more than 100 strains of the genus Frankia showed that restriction enzyme DraI (recognition site, TTT'AAA) gave rise to large DNA fragments (200 to 1,500 kb), which, when they were subjected to cluster analysis, reflected the host plants from which the strains were isolated. Our results support the conclusions of Lalonde and his colleagues (M. Lalonde, L. Simon, J. Bousquet, and A. Seguin, p. 671-680, in H. Bothe, F. J. de Bruijn, and W. E. Newton, ed., Nitrogen Fixation: Hundred Years After, 1988; P. Normand, P. Simonet, and R. Bardin, Mol. Gen. Genet. 213:238-246, 1988) and Fernandez et al. (M. P. Fernandez, H. Meugnier, P. A. D. Grimont, and R. Bardin, Int. J. Syst. Bacteriol. 39:424-429, 1989) that various biochemical and genomic analyses can give rise to groupings of $F$ rankia strains that are consistent with the host plants from which the strains are isolated and that the resulting groups may form a basis for defining Frankia species.
\end{abstract}

In a very real sense, Frankia taxonomy has come full circle. A strain of these nitrogen-fixing actinomycete symbionts of higher plants was first isolated and maintained in pure culture only 14 years ago (15). As more pure strains were isolated, it became apparent that the taxonomic scheme of Becking $(9,10)$, which was formulated prior to the availability of the endophytes in pure culture, was not entirely satisfactory (27). Becking followed the lead of Rhizobium taxonomists in basing Frankia species definitions on host plant compatibility which was determined by using crushed-nodule inocula. When the pure cultures were used to determine infectivity, it became clear that Becking's host plant infectivity groups were not entirely correct. In addition, although Becking accurately described the morphology of frankiae from nodule sections, his attempt at describing the cell chemistry of these organisms was flawed because of the high levels of plant impurities present in his preparations. In addition, other workers found that Frankia isolates were not amenable to classification on the basis of the results of tests that are commonly used for assigning actinomycetes to species $(14,30)$. This was not only because of the exceedingly slow growth of these organisms (doubling times, 1 to 5 days) and their nutritional diversity, but also because many frankiae, like the slow-growing rhizobia, are relatively inactive, as assessed by dissimilation of carbohydrates and other substances. Consequently, in 1983 workers in the field agreed that it would be inappropriate to use Becking's species names until solid criteria could be developed to group the various isolates in a taxonomically meaningful way (27).

Recently, Lalonde and coworkers (24), summarizing a number of their own studies and studies of other workers, concluded that the evidence that has been accumulated to date points strongly to the plant host relationship as an important element in the definition of Frankia species. The data which were used in these studies included data on polypeptide patterns, serology, isozyme patterns, glycoside patterns, fatty acid composition, DNA homology, and nifprobed restriction fragment length polymorphisms. Although not always based on the same pool of strains, these

\footnotetext{
* Corresponding author.

† Present address: RR2, Box 2235, Morrisville, VT 05661.
}

data supported the proposals that Becking's species Frankia alni and Frankia elaeagnii should be redescribed and that two subspecies should be created in $F$. alni, " $F$. alni subsp. pommerii" and " $F$. alni subsp. vandijkii." On the basis of DNA-DNA relatedness data, Fernandez et al. (21) subsequently proposed nine "genomic species" of the genus Frankia which also reflected host plant relationships. Genomic species 1 of Fernandez et al. was considered to be equivalent to $F$. alni. In this paper we report that on the basis of the distribution of high-molecular-weight restriction fragments of DNAs of members of this genus, we also identified clusters of strains which reflected the host plants from which the strains were isolated.

\section{MATERIALS AND METHODS}

Bacterial strains. The strains used in this study and their origins are shown in Table 1 . These strains were maintained in various liquid media, including $\mathrm{L} / 2, \mathrm{~S}, \mathrm{~S}+\mathrm{Tw}, \mathrm{HIML} 3$, $B / 2$, and $L+S_{2}(31)$, and were transferred every 4 to 6 months. For analysis the strains were grown in a defined medium (DPM, DPM/N, or DPM/N2Pyr [31]) under static conditions at $28^{\circ} \mathrm{C}$ and were harvested in the stationary phase. The length of incubation varied with the growth rate of the strains, but was usually 6 to 10 weeks.

Preparation of inserts. The cells were collected and washed with $10 \mathrm{mM}$ Tris-1 mM disodium EDTA buffer ( $\mathrm{pH}$ 7.4) (TE), ground, and then treated by shaking them at $65^{\circ} \mathrm{C}$ for 30 min with $2 \%$ sodium dodecyl sulfate- $5 \mathrm{mM}$ disodium EDTA. After the cells were washed with $5 \mathrm{mM}$ disodium EDTA containing $1 \mathrm{mg}$ of bovine serum albumin fraction $\mathrm{V}$ per $\mathrm{ml}$, they were washed with decreasing concentrations of pH 8.4 disodium EDTA $(0.5 \mathrm{M}, 0.25 \mathrm{M}$, and $5 \mathrm{mM})$ to remove as much sodium dodecyl sulfate as possible; finally, the cells were extracted for $20 \mathrm{~min}$ at room temperature with chloroform-ethanol $(2: 1)$ and then with acetone by using a wrist action shaker. The solvents were discarded, and then the cells, after they were rehydrated in TE for 20 to $30 \mathrm{~min}$, were ground with a Ten Broeck tissue grinder. Inserts for pulsedfield analysis were prepared in $0.5 \%$ (final concentration) low-melting-point agarose in TE and then incubated with gentle shaking at $37^{\circ} \mathrm{C}$ for 4 to $5 \mathrm{~h}$ or overnight in EC lysis buffer (38) (6 mM Tris hydrochloride [pH 7.6], $1 \mathrm{M}$ sodium chloride, $100 \mathrm{mM}$ EDTA [pH 7.5], 0.5\% Brij 58, 0.2\% 


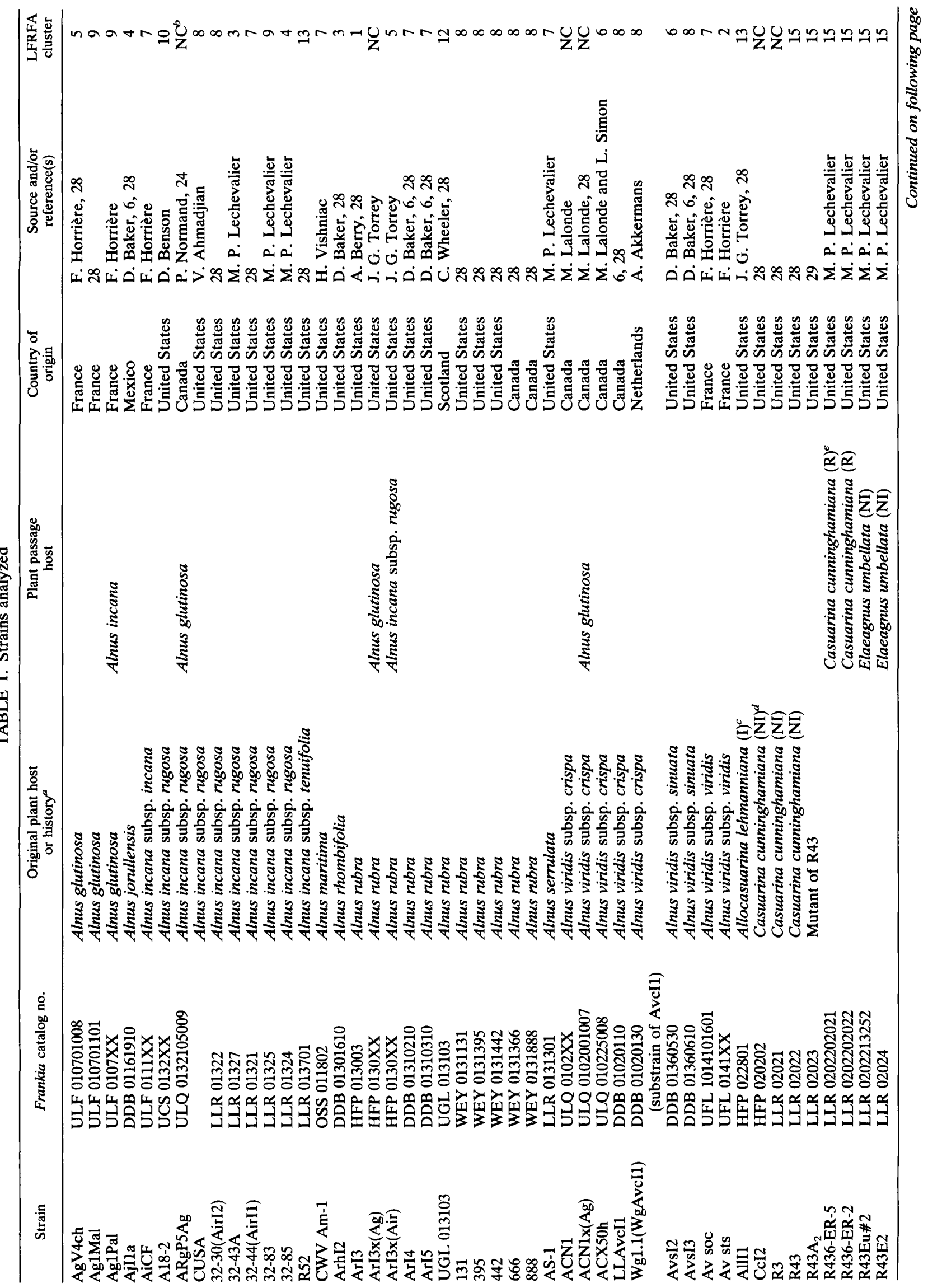




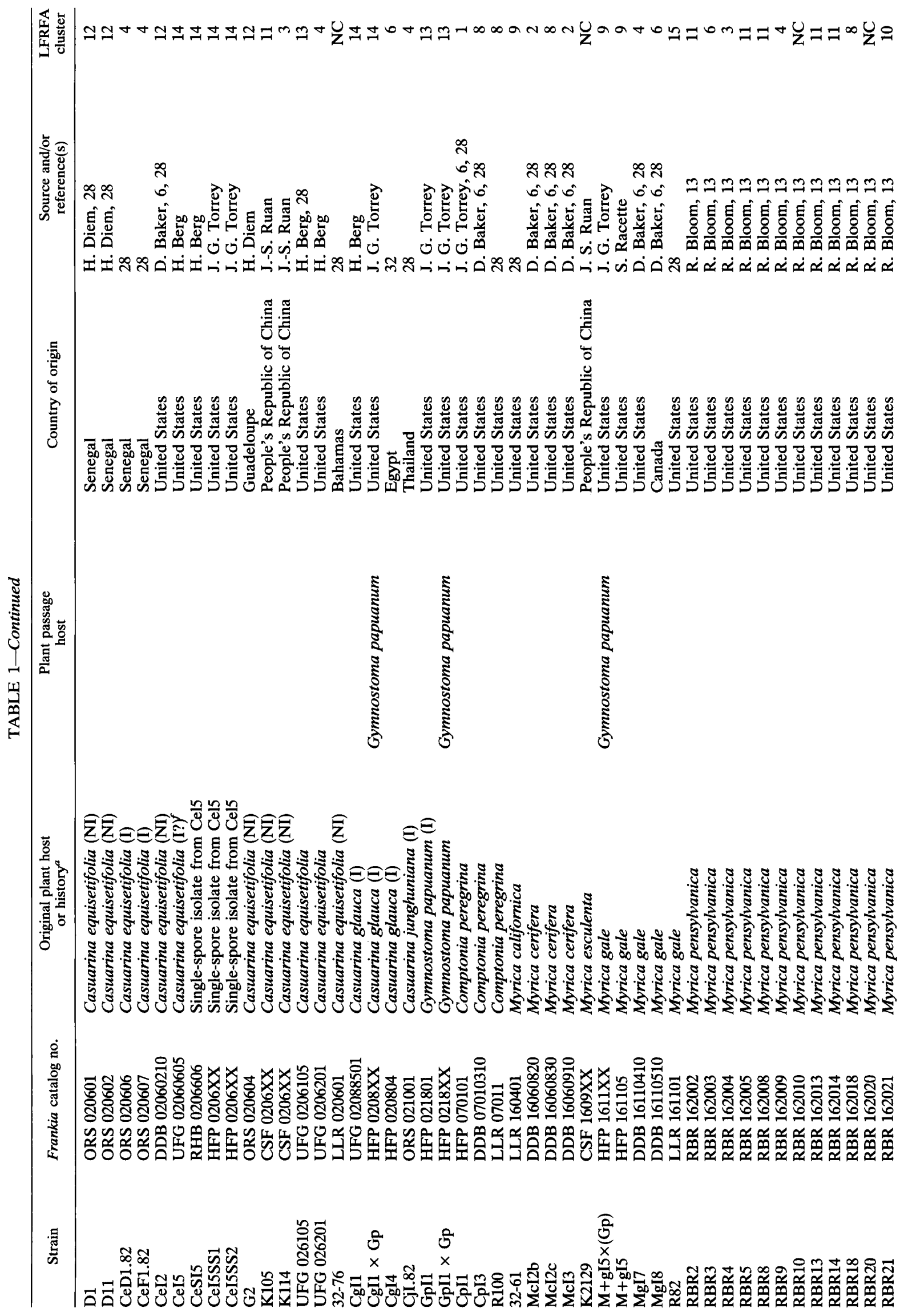




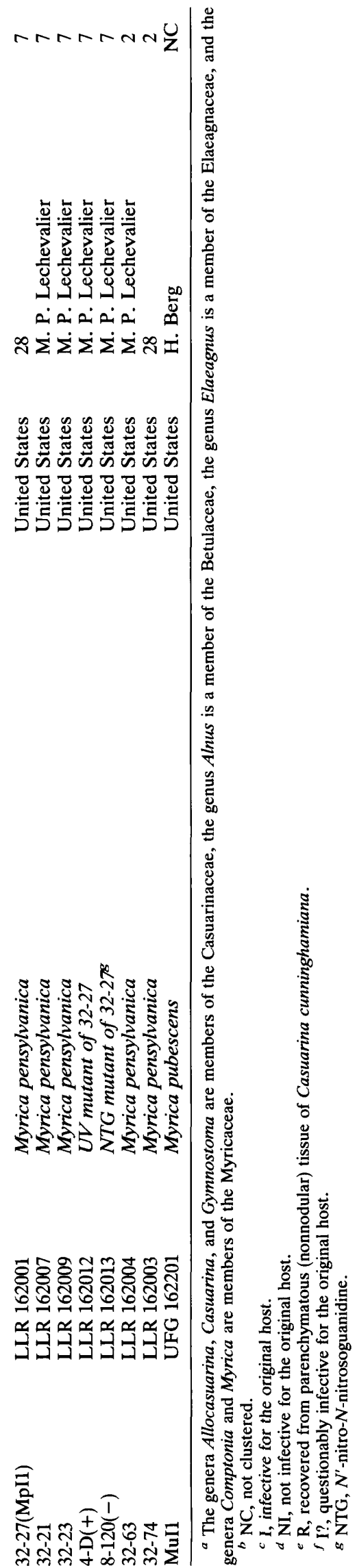

sodium deoxycholate, $0.1 \% \mathrm{~N}$-laurylsarcosine) containing 2 $\mathrm{mg}$ of lysozyme per $\mathrm{ml}$. The inserts were next treated with TE containing $1 \mathrm{mg}$ of subtilisin Carlsberg (catalog no. P5380; Sigma Chemical Co., St. Louis, Mo.) per ml with shaking overnight; this was followed by two washes in TE at $56^{\circ} \mathrm{C}$ for $4 \mathrm{~h}$ or overnight and then two washes in TE at $56^{\circ} \mathrm{C}$ for $2 \mathrm{~h}$. Restriction digestion with DraI was carried out as described by Smith and Cantor (38), using the buffers recommended by the suppliers of the enzyme.

Pulsed-field electrophoresis. Pulsed-field electrophoresis was performed by using a $0.8 \%$ agarose gel in $1 \%$ Trisborate buffer $(0.1 \mathrm{M}$ Tris base, $0.1 \mathrm{M}$ boric acid, $0.2 \mathrm{mM}$ disodium EDTA) in a Beckman Geneline transverse alternating field electrophoresis (TAFE) apparatus. The following program was used for 200 - to 1,500 -kb fragments: $12 \mathrm{~h}$ at $150 \mathrm{~V}$ with 70 -s pulses, followed by $14 \mathrm{~h}$ at $150 \mathrm{~V}$ with 120 -s pulses. For 50 - to $500-\mathrm{kb}$ fragments the following program was used: $20 \mathrm{~h}$ at $140 \mathrm{~mA}$ with $25-\mathrm{s}$ pulses. The standards used for the DNA bands at the higher molecular weights were Saccharomyces cerevisiae 334 chromosomes (catalog no. 338404; Beckman Instruments, Inc.), and lambda concatemers (Beckman Instruments) were the standards used for the lower-molecular-weight range. Ethidium bromidestained gels were visualized at $302 \mathrm{~nm}$ and were photographed with type 55 or 57 Polaroid film.

Data analysis. Similarity values were calculated by using the Taxan program (version 2.0) of David Swartz, Biotechnology Institute, University of Maryland (the simple matching $\left[S_{\mathrm{SM}}\right]$ algorithm and cluster analysis by the unweighted average pair group method [39]).

\section{RESULTS}

We analyzed the DNAs of more than 100 Frankia strains to determine their DraI restriction patterns (recognition site TTT'AAA) by using pulsed-field electrophoresis (low-frequency restriction fragment analysis [LFRFA]). The strains were isolated from nodules from members of the plant genera Alnus, Myrica, Comptonia, Casuarina, Allocasuarina, and Gymnostoma growing in widely different areas of the world (United States, Canada, Scotland, Mexico, Egypt, France, Bahamas, Thailand, Senegal, Guadeloupe, and Pcople's Republic of China) (Table 1). The sizes of the DNA fragments in the size range from 200 to $1,000 \mathrm{~kb}$ were determined by comparing them with a $S$. cerevisiae chromosomal standard, and the unweighted data were clustered by using the $S_{\mathrm{SM}}$ algorithm (39) (Fig. 1). Included in this comparison were wild-type strains, strains that were reisolated after plant passage, single-spore isolates, mutants, and co-isolates (different strains from a single nodule). We identified 15 clusters that were linked at levels of $>75 \%$ and contained 90 strains; 11 strains did not fall into any cluster. In general, the clusters tended to be dominated either by strains that were isolated from members of the Casuarinaceae (Fig. 1) (e.g., clusters 12 through 15) or by strains that were isolated from Alnus spp. and members of the Myricaceae (e.g., clusters 1, 2, and 5 through 11). Clusters 3 and 4 were considered mixed, since they had no predominant group. The electrophoretic LFRFA patterns of some representative strains are shown in Fig. 2.

Table 2 shows the distribution of DraI fragments in various size ranges (see above) for each cluster. Substrains (such as single-spore isolates) that were known to have been derived from one of the strains in a cluster and produced LFRFA patterns that were identical to the pattern of the parent were omitted from the calculations. Table 2 also 


\section{$\%$ s sm}

LFRFA

\begin{tabular}{l|l|l|l|}
100 & 90 & 80 & 70
\end{tabular}

10 60 50

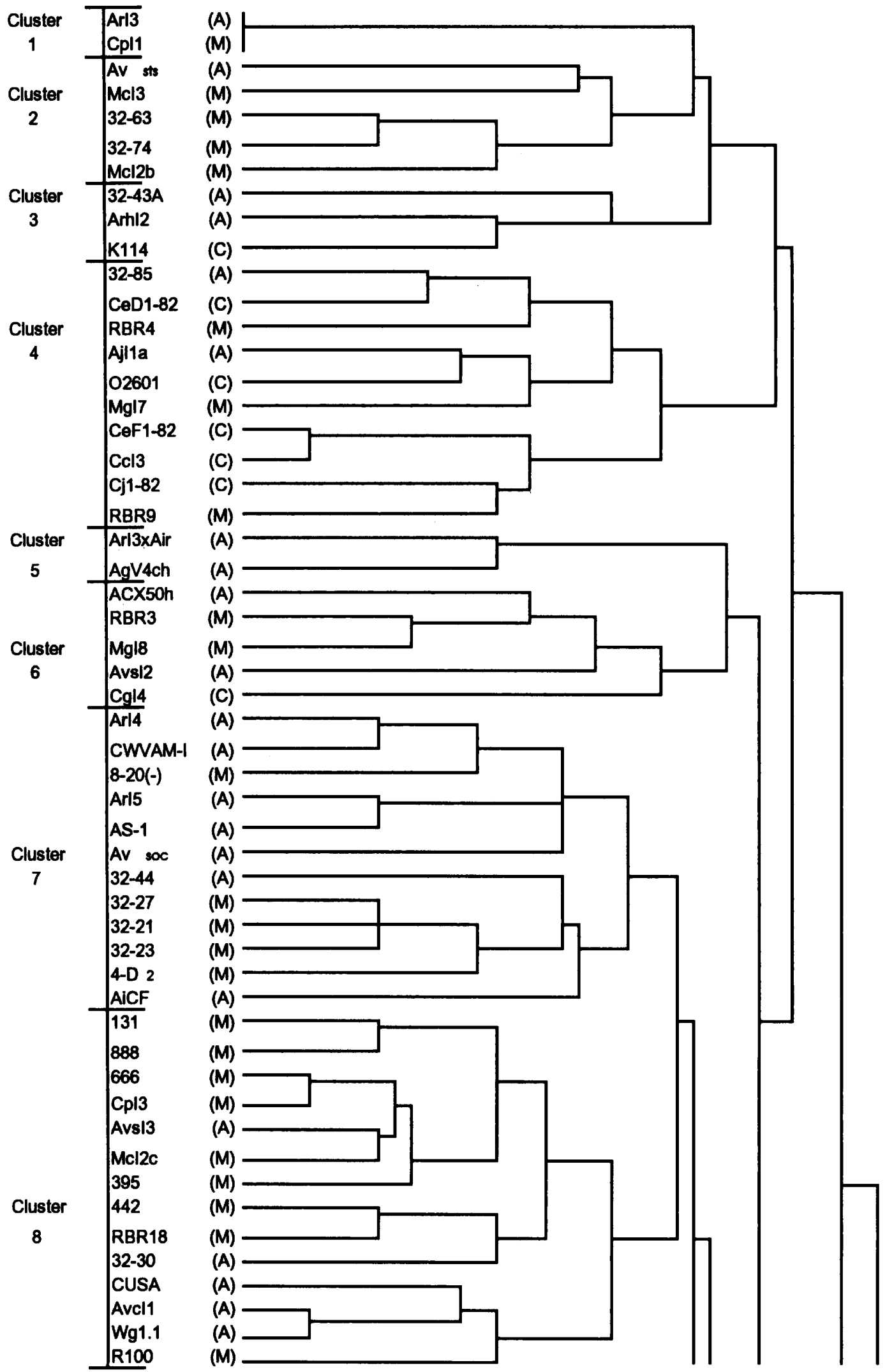




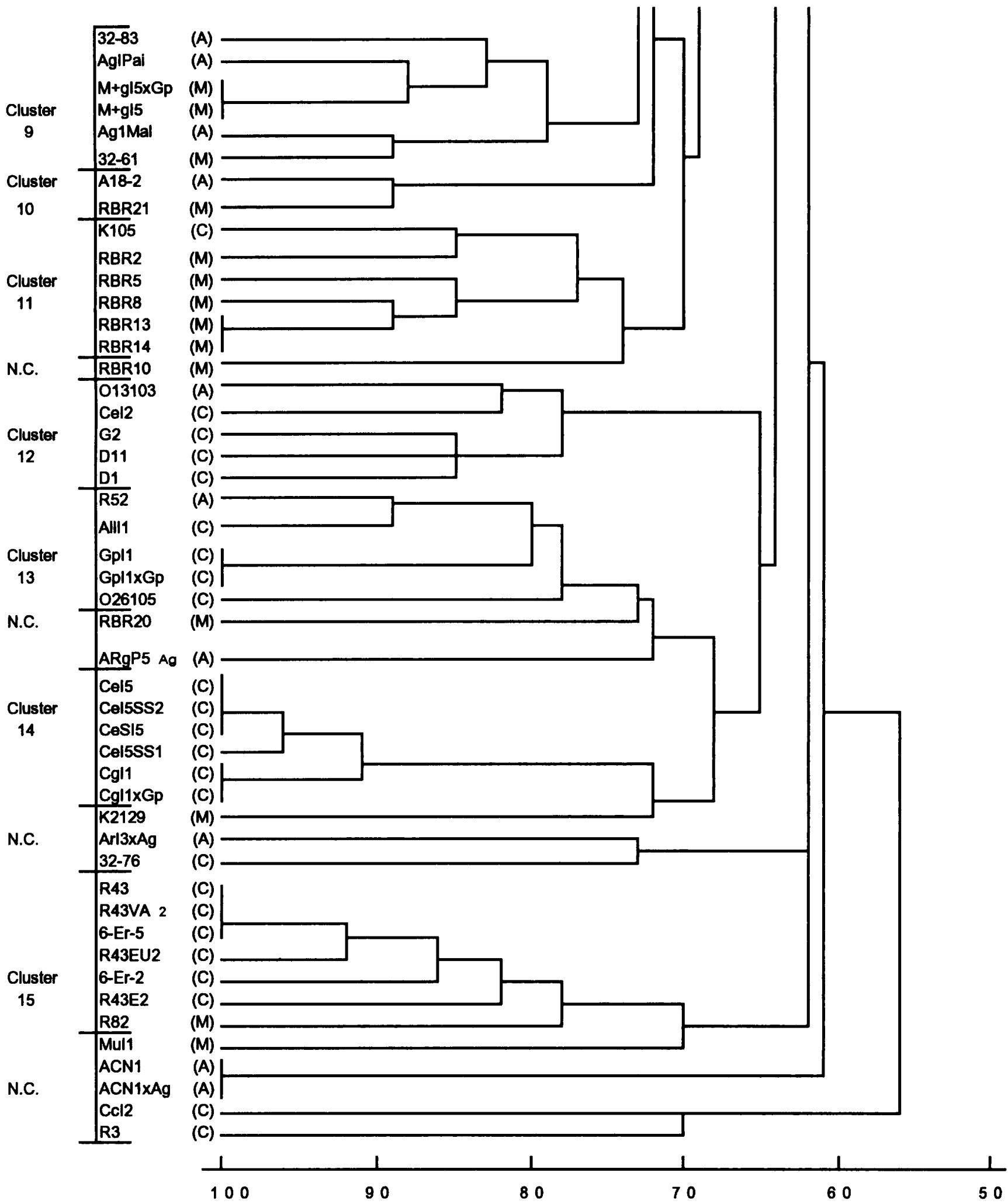

FIG. 1. Dendrogram constructed by performing an unweighted average linkage cluster analysis of $S_{\mathrm{SM}}$ values of DNA fragment sizes expressed as percentages. The DNA of each of the 101 Frankia strains obtained from the plant genera Alnus, Myrica, Comptonia, Allocasuarina, Casuarina, and Gymnostoma (see Table 1 for descriptions of the strains) was digested with DraI, and the sizes of the resulting DNA fragments were calculated (see text). (A), strains obtained from Alnus spp.; (M), strains obtained from Myrica and Comptonia spp. (members of the family Myricaceae); (C), strains obtained from Allocasuarina, Casuarina, and Gymnostoma spp. (members of the family Casuarinaceae). N.C., not clustered. 
TABLE 2. Distribution of DraI fragments of various sizes within the LFRFA clusters of Frankia strains

\begin{tabular}{|c|c|c|c|c|c|c|c|c|c|c|c|c|c|c|c|c|}
\hline \multirow{2}{*}{$\begin{array}{l}\text { Clus- } \\
\text { ter }\end{array}$} & \multirow{2}{*}{$\begin{array}{l}\text { No. of } \\
\text { strains }\end{array}$} & \multicolumn{3}{|c|}{$\begin{array}{l}\text { No. of strains with the } \\
\text { following plant hosts: }\end{array}$} & \multicolumn{12}{|c|}{$\%$ of $D r a \mathrm{I}$ fragments in the following size ranges: } \\
\hline & & $\begin{array}{l}\text { Alnus } \\
\text { spp. }\end{array}$ & $\begin{array}{l}\text { Members of } \\
\text { the Myricaceae }\end{array}$ & $\begin{array}{l}\text { Members of the } \\
\text { Casuarinaceae }\end{array}$ & $\begin{array}{l}<240 \\
\mathbf{k b}\end{array}$ & $\begin{array}{l}240 \text { to } \\
269 \mathrm{~kb}\end{array}$ & $\begin{array}{l}270 \text { to } \\
299 \mathrm{~kb}\end{array}$ & $\begin{array}{l}300 \text { to } \\
329 \mathrm{~kb}\end{array}$ & $\begin{array}{l}330 \mathrm{to} \\
359 \mathrm{~kb}\end{array}$ & $\begin{array}{l}360 \text { to } \\
389 \mathrm{~kb}\end{array}$ & $\begin{array}{l}390 \mathrm{to} \\
419 \mathrm{~kb}\end{array}$ & $\begin{array}{l}420 \text { to } \\
449 \mathrm{~kb}\end{array}$ & $\begin{array}{l}450 \mathrm{to} \\
479 \mathrm{~kb}\end{array}$ & $\begin{array}{l}480 \mathrm{to} \\
509 \mathrm{~kb}\end{array}$ & $\begin{array}{l}510 \text { to } \\
539 \mathrm{~kb}\end{array}$ & $\begin{array}{l}540 \text { to } \\
569 \mathrm{~kb}\end{array}$ \\
\hline 1 & 2 & 1 & 1 & 0 & 100 & 100 & 100 & 0 & 100 & 0 & 100 & 0 & 0 & 0 & 100 & 0 \\
\hline 2 & 5 & 1 & 4 & 0 & 100 & 80 & 100 & 0 & 60 & 60 & 0 & 0 & 80 & 0 & 20 & 20 \\
\hline 3 & 3 & 2 & 0 & 1 & 100 & 33 & 100 & 0 & 0 & 33 & 66 & 0 & 0 & 0 & 0 & 0 \\
\hline 4 & 10 & 2 & 3 & 5 & 60 & 50 & 60 & 0 & 0 & 40 & 50 & 0 & 90 & 30 & 20 & 0 \\
\hline 5 & 2 & 2 & 0 & 0 & 50 & 100 & 100 & 0 & 100 & 0 & 0 & 50 & 0 & 0 & 0 & 0 \\
\hline 6 & 5 & 2 & 2 & 1 & 80 & 0 & 100 & 0 & 0 & 0 & 20 & 0 & 80 & 40 & 20 & 60 \\
\hline 7 & 12 & 7 & 5 & 0 & 92 & 0 & 83 & 0 & 0 & 17 & 50 & 66 & 0 & 0 & 50 & 0 \\
\hline 8 & 14 & 10 & 4 & 0 & 100 & 0 & 0 & 7 & 7 & 7 & 0 & 0 & 21 & 0 & 14 & 0 \\
\hline 9 & 5 & 3 & 2 & 0 & 0 & 20 & 80 & 0 & 0 & 40 & 0 & 40 & 20 & 0 & 40 & 0 \\
\hline 10 & 2 & 1 & 1 & 0 & 100 & 0 & 0 & 0 & 0 & 100 & 0 & 100 & 0 & 0 & 0 & 50 \\
\hline 11 & 6 & 0 & 5 & 1 & 80 & 0 & 17 & 0 & 100 & 0 & 0 & 50 & 17 & 0 & 33 & 0 \\
\hline 12 & 5 & 1 & 0 & 4 & 100 & 40 & 100 & 0 & 0 & 80 & 100 & 40 & 20 & 0 & 60 & 100 \\
\hline 13 & 4 & 1 & 0 & 3 & 100 & 0 & 100 & 0 & 0 & 50 & 25 & 50 & 0 & 100 & 0 & 100 \\
\hline 14 & 3 & 0 & 0 & 3 & 100 & 100 & 100 & 0 & 0 & 33 & 0 & 100 & 100 & 100 & 0 & 100 \\
\hline 15 & 5 & 0 & 1 & 4 & 100 & 100 & 80 & 0 & 100 & 0 & 100 & 20 & 60 & 20 & 0 & 20 \\
\hline
\end{tabular}

shows the average number of fragments for each cluster, as well as the range of number of fragments. The average number of DraI fragments was higher for isolates obtained from members of the Casuarinaceae (average number of fragments, 9; range, 4 to 12 ) than for isolates obtained from members of the Myricaceae (average, 7; range, 3 to 14) or from Alnus spp. (average, 6; range, 3 to 10 ).

Under the experimental conditions that are used now, not all frankiae can be shown to reinfect the hosts from which they were isolated $(7,18)$, and some frankiae are not

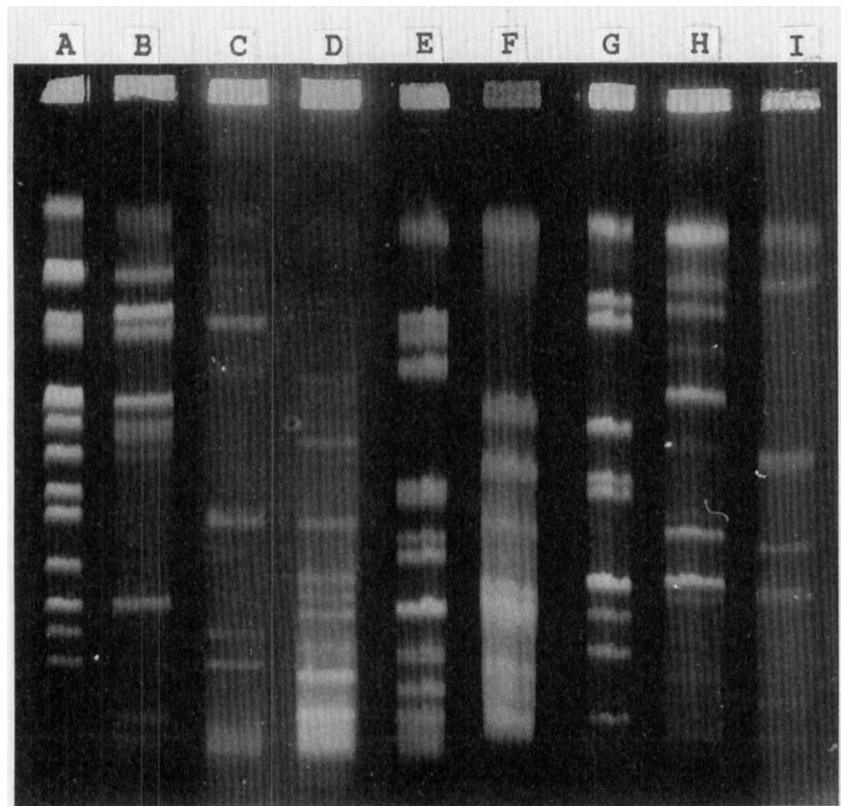

FIG. 2. Gel obtained by pulsed-field electrophoresis of DraIdigested DNAs from some representative Frankia strains. Lane A, standard ( $S$. cerevisiae chromosomes; sizes [from bottom to top] $260,290,370,460,580,650,763,835,864,991,1,047,1,285$, and $1,500 \mathrm{~kb}$ ); lane B, Alnus isolate ArI4; lane C, Alnus isolate 32-83; lane D, Alnus isolate Agv4ch; lane E, Alnus isolate ARgP5 ${ }^{\mathrm{AG}}$; lane F, Casuarina isolate CeI2; lane G, Myrica isolate RBR3; lane H, Myrica isolate RBR18; lane I, Myrica isolate 32-27. infective for any plant yet tested (8). For example, most isolates obtained from Alnus, Myrica, and Comptonia spp. are infective for their original hosts, but many strains obtained from other hosts, including Casuarina, Elaeagnus, Hippophae, Ceanothus, and Purshia spp., are not. As determined by LFRFA, noninfective strains obtained from members of the Casuarinaceae (found in clusters 3, 11, 12, and 15 or unclustered) (Fig. 1 and Table 1) did not cluster with infective strains (clusters 4, 6, 13, and 14). However, this was not true for either the noninfective strains obtained from Alnus spp. (strains ArhI2 and R52) or the noninfective strains obtained from members of the Myricaceae (strains MgI2b, MgI2c, MgI3, MgI7, MgI8, and R100). We also examined 22 strains (obtained from Comptonia, Alnus, Myrica, and Casuarina spp.) whose actual experimental infectivity characteristics (host compatibility groups [7, 8]) have been determined. The conclusion remained the same as the conclusion in the global analysis; the host plant from which a strain was isolated, not the infective capacity of the strain as determined under greenhouse conditions, largely dictated the cluster into which the strain fell (Table 3).

Relationship of LFRFA data to DNA-DNA relatedness data. With one exception (strain RBR5), a number of isolates obtained from a single plant host species (Myrica pensylvanica) whose DNA relatedness values have been determined previously (13) exhibited relationships that were very similar to relationships determined by DNA complementarity ranking when they were clustered by using LFRFA (Table 4). LFRFA cluster data for 11 strains common to this study and the DNA relatedness study of Fernandez et al. (21) showed that the clusters determined in the two studies were in substantial agreement (Fig. 3); 8 of 11 (73\%) of the strains clustered similarly (the strains which exhibited differences were strains $\mathrm{ARgP5}^{\mathrm{Ag}}$, AllI1, and $\mathrm{ACN} 1^{\mathrm{Ag}}$ ). The strains in LFRFA cluster A corresponded to genomic species 1 of Fernandez et al., but strain $\mathrm{ACN}^{\mathrm{Ag}}$, which was also assigned to genomic species 1 by Fernandez et al., did not cluster in the LFRFA. Strains D11 and CcI2 did not cluster in either study. Strains ARgP5 ${ }^{\mathbf{A g}}$ and AllI1 were members of LFRFA cluster $B$, but were assigned to two different genomic species (genomic species 3 and 9 , respectively) by Fernandez et al. Strains CeF1.82, CcI3, CeD1.82, and Cj1.82 formed a single cluster in both studies. 
TABLE 2-Continued

$\%$ of DraI fragments in the following size ranges:

No. of bands

\begin{tabular}{|c|c|c|c|c|c|c|c|c|c|c|c|c|c|c|c|c|}
\hline $\begin{array}{l}570 \mathrm{to} \\
599 \mathrm{~kb}\end{array}$ & $\begin{array}{l}600 \text { to } \\
629 \mathrm{~kb}\end{array}$ & $\begin{array}{l}630 \text { to } \\
659 \mathrm{~kb}\end{array}$ & $\begin{array}{l}660 \mathrm{to} \\
689 \mathrm{~kb}\end{array}$ & $\begin{array}{l}690 \text { to } \\
719 \mathrm{~kb}\end{array}$ & $\begin{array}{l}720 \text { to } \\
749 \mathrm{~kb}\end{array}$ & $\begin{array}{l}750 \mathrm{to} \\
769 \mathrm{~kb}\end{array}$ & $\begin{array}{l}770 \text { to } \\
799 \mathrm{~kb}\end{array}$ & $\begin{array}{l}800 \text { to } \\
829 \mathrm{~kb}\end{array}$ & $\begin{array}{l}830 \text { to } \\
859 \mathrm{~kb}\end{array}$ & $\begin{array}{l}860 \text { to } \\
889 \mathrm{~kb}\end{array}$ & $\begin{array}{l}890 \text { to } \\
919 \mathrm{~kb}\end{array}$ & $\begin{array}{l}920 \text { to } \\
949 \mathrm{~kb}\end{array}$ & $\begin{array}{l}950 \text { to } \\
979 \mathrm{~kb}\end{array}$ & $\begin{array}{c}980 \text { to } \\
1,000 \mathrm{~kb}\end{array}$ & Avg & Range \\
\hline 0 & 0 & 100 & 0 & 0 & 0 & 0 & 100 & 100 & 100 & 0 & 0 & 100 & 0 & 0 & 11 & \\
\hline 0 & 0 & 80 & 0 & 0 & 0 & 60 & 0 & 20 & 100 & 40 & 0 & 60 & 0 & 0 & 9 & $6-10$ \\
\hline 66 & 0 & 66 & 0 & 0 & 66 & 0 & 0 & 33 & 33 & 0 & 0 & 100 & 0 & 0 & 7 & $6-8$ \\
\hline 30 & 0 & 10 & 0 & 70 & 0 & 0 & 0 & 10 & 80 & 10 & 0 & 0 & 0 & 10 & 6 & 3-9 \\
\hline 100 & 0 & 0 & 0 & 0 & 0 & 0 & 0 & 100 & 50 & 100 & 0 & 0 & 0 & 50 & 7 & $5-9$ \\
\hline 0 & 0 & 40 & 0 & 0 & 0 & 40 & 20 & 40 & 0 & 100 & 0 & 0 & 0 & 40 & 7 & 4-9 \\
\hline 17 & 8 & 0 & 8 & 8 & 0 & 66 & 0 & 75 & 25 & 42 & 0 & 8 & 0 & 17 & 6 & $5-7$ \\
\hline 36 & 21 & 7 & 0 & 0 & 0 & 36 & 0 & 14 & 78 & 43 & 0 & 43 & 0 & 71 & 5 & $3-7$ \\
\hline 20 & 0 & 0 & 0 & 0 & 0 & 40 & 0 & 0 & 20 & 0 & 0 & 0 & 0 & 100 & 4 & $3-7$ \\
\hline 0 & 50 & 0 & 0 & 0 & 50 & 0 & 50 & 0 & 100 & 0 & 0 & 0 & 0 & 0 & 6 & 4-7 \\
\hline 17 & 0 & 33 & 0 & 66 & 17 & 0 & 0 & 17 & 0 & 0 & 17 & 100 & 0 & 66 & 6 & $6-7$ \\
\hline 0 & 0 & 80 & 0 & 20 & 20 & 20 & 0 & 60 & 80 & 0 & 0 & 0 & 0 & 100 & 10 & $8-12$ \\
\hline 25 & 0 & 0 & 0 & 25 & 25 & 25 & 0 & 25 & 75 & 0 & 0 & 75 & 25 & 0 & 8 & $5-10$ \\
\hline 0 & 0 & 100 & 0 & 0 & 0 & 0 & 0 & 66 & 33 & 0 & 100 & 0 & 0 & 0 & 10 & 9-11 \\
\hline 40 & 0 & 20 & 0 & 0 & 0 & 0 & 0 & 0 & 40 & 0 & 80 & 0 & 80 & 100 & 10 & $8-10$ \\
\hline
\end{tabular}

Such a relationship was less apparent for a groups of nine strains obtained from Alnus spp. and members of the Myricaceae and the Casuarinaceae whose DNA hybridization values have also been determined previously (2) (Table 5). A recent study (34) on the levels of DNA relatedness of 11 Frankia strains included only two strains that were also included in our study (strains K114 and ArI4). Shi et al. (34) found that the level of DNA relatedness between these two strains was very low (15\%); as determined by our LFRFA, the level of relatedness was also low $(66 \%)$.

TABLE 3. Clusters of Frankia strains compared with host compatibility groups and original hosts

\begin{tabular}{|c|c|c|c|}
\hline Cluster $^{a}$ & Strain & $\begin{array}{l}\text { Host compatibility } \\
\text { group }^{b}\end{array}$ & $\begin{array}{c}\text { Taxon of } \\
\text { original host }\end{array}$ \\
\hline \multirow[t]{2}{*}{ I } & CpI1 & 1 & Myricaceae \\
\hline & ArI3 & 1 & Alnus \\
\hline \multirow[t]{6}{*}{ II } & $\mathrm{McI} 2 \mathrm{~b}$ & 3 & Myricaceae \\
\hline & CeD1.82 & 2 & Casuarinaceae \\
\hline & $\mathrm{McI3}$ & 3 & Myricaceae \\
\hline & $\mathrm{CcI3}$ & 2 & Casuarinaceae \\
\hline & CeF1.82 & 2 & Casuarinaceae \\
\hline & MgI8 & 4 & Myricaceae \\
\hline \multirow[t]{3}{*}{ III } & D11 & 3 & Casuarinaceae \\
\hline & $\mathrm{G} 2$ & 3 & Casuarinaceae \\
\hline & $\mathrm{CeI} 2$ & 3 & Casuarinaceae \\
\hline \multirow[t]{6}{*}{ IV } & CpI3 & 1 & Myricaceae \\
\hline & AirI1 & 1 & Alnus \\
\hline & $\operatorname{MgI7}$ & 4 & Myricaceae \\
\hline & ArI4 & 1 & Alnus \\
\hline & ArI5 & 1 & Alnus \\
\hline & Avcl3 & 3 & Alnus \\
\hline \multirow[t]{2}{*}{ V } & ArhI2 & 3 & Alnus \\
\hline & $32-30$ & 1 & Alnus \\
\hline \multirow[t]{4}{*}{ Not clustered } & R52 & NI & Alnus \\
\hline & R100 & NI? & Myricaceae \\
\hline & R43 & 3 & Casuarinaceae \\
\hline & MgI1 & 4 & Myricaceae \\
\hline
\end{tabular}

Clusters formed at levels of similarity of $>75 \%\left(S_{\mathrm{SM}}\right)$.

${ }^{b}$ See reference 7 . NI, noninfective; host compatibility group 1 , infective for Alnus and Myrica spp.; host compatibility group 2, infective for members of the Casuarinaceae and Myrica spp.; host compatibility group 3, infective for members of the Elaeagnaceae and Myrica spp.; host compatibility group 4, infective only for members of the Elaeagnaceae.
Stability of LFRFA patterns. We also observed that the LFRFA patterns of a strain can vary spontaneously. An analysis of single-spore isolates obtained from Frankia sp. strain CeI5 (isolates CeSI5, CeI5SS1, CeI5SS2, and CeI5SS3) showed that two of them (isolates CeI5SS1 and CeI5SS2) differed from the parent by one or two fragments (Fig. 4). In contrast, nine single-spore isolates of Frankia sp. strain CcI3 were identical to the parent strain (data not shown). Plant passage could also affect LFRFA patterns. Substrains of Frankia sp. strain R43 passed through Elaeagnus umbellata (substrains R43EU2 and R43E2) and $\mathrm{Ca}$ suarina cunninghamiana (substrain R43Er-2, which was reisolated from parenchymatous root tissue) differed from the original strain (Fig. 4). Despite their differences, the changed substrains clustered at levels of $>75 \%$ with the parent. Other reisolates obtained from these same plant experiments were unchanged. No changes were found in substrains of strain Wg1.1 (substrains Wg1.1r4, Wg1.1r5, and Wg1.1r9) passed through Alnus glutinosa, a substrain of strain ACN1 passed through the same host (substrain $\mathrm{ACN} 1^{\mathrm{Ag}}$ ), a substrain of strain $\mathrm{CcI} 2$ passed through Gymnostoma papuanum (substrain $\mathrm{CcI} 2 \mathrm{xGp}$ ), and a substrain of strain CcI3 passed through Casuarina cunninghamiana (substrain $\mathrm{CcI} 3 \mathrm{xCc}$ ). A substrain of strain ArI3 passed through Alnus glutinosa (substrain ArI3xAg) was the only plant-

TABLE 4. Levels of DNA relatedness and levels of LFRFA homology for Frankia strains obtained from Myrica pensylvanica

\begin{tabular}{lrc}
\hline Strain & $\begin{array}{c}\text { \% DNA relatedness } \\
\text { to strain RBR13 }\end{array}$ & $\begin{array}{c}\text { \% LFRFA homology } \\
\text { with strain RBR13 }\end{array}$ \\
\hline RBR13 & 100 & 100 \\
RBR14 & 98 & 100 \\
RBR10 & 98 & 90 \\
RBR8 & 99 & 85 \\
RBR18 & 59 & 65 \\
RBR5 & 12 & 68 \\
RBR20 & 54 & 68 \\
RBR21 & 57 & 63 \\
RBR3 & 48 & 60 \\
RBR9 & 35 & 47 \\
\hline
\end{tabular}

${ }^{a}$ Data from reference 13

${ }^{b}$ As determined by using the $S_{\mathrm{SM}}$. 


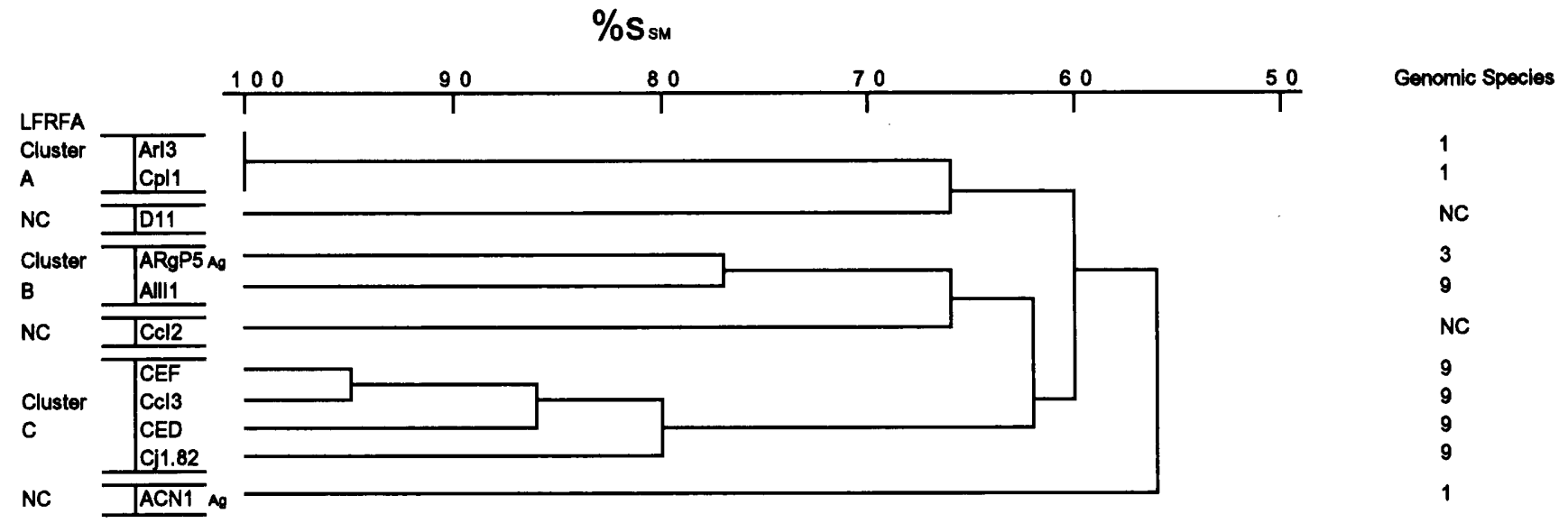

FIG. 3. Dendrogram showing 11 Frankia strains obtained from Alnus spp. (strains ArI3 and ACN1 ${ }^{\mathrm{Ag}}$ ) and members of the Myricaceae (strain CpI1) and the Casuarinaceae (strains CcI2, CcI3, CED1.82, CEF1.82, Cj1.82, and D11) clustered for comparison with the genomic species assignments of Fernandez et al. (21). See text. NC, not clustered.

passed substrain that did not cluster reasonably closely with its parent (level of similarity, 67\%) and may have been a contaminant.

It is perhaps worth noting that isolates AvcI1 and Wg1.1 (a substrain of strain AvcI1) clustered at a level of only $96 \%$ in our experiments. Strain AvcI1 was originally described by Baker and Torrey in 1980 (5) and was sent to the laboratory of A. Akkermans in Wageningen, The Netherlands, at about that time. After an interval of several years, the strain in the Netherlands (strain Wg 1.1 [= WgAvcI1]) was sent to the University of Tennessee, where An et al. (3) compared its DNA restriction patterns with those of the original strain. Using five different restriction enzymes, these authors identified several major new bands in strain Wg 1.1, showing that genetic variation had occurred. Using LFRFA, we observed that the original strain AvcI1 produced six major bands, whereas strain Wg1.1 produced only five bands, thus confirming the genetic variation observed by An et al.

Coisolates (strains isolated from the same plant nodule) sometimes varied slightly in their LFRFA patterns (for example, strains 32-63 and 32-74 obtained from Myrica pensylvanica in New Jersey [Fig. 5] and strains 32-37 and 32-21 obtained from Myrica pensylvanica in Massachusetts [Fig. 6]). Both of these pairs of strains clustered at a level of $92 \%$. Even isolates obtained from two plants belonging to different species growing in the same region can be very similar; for example, strains $\mathrm{CgI} 1$ and $\mathrm{CeI5}$, which were

TABLE 5. Levels of DNA relatedness and levels of LFRFA homology for various Frankia strains

\begin{tabular}{|c|c|c|}
\hline Strain & $\begin{array}{l}\% \text { DNA relatedness } \\
\text { to strain ArI } 4^{a}\end{array}$ & $\begin{array}{l}\text { \% LFRFA homology } \\
\text { with strain ArI } 4^{b}\end{array}$ \\
\hline ArI4 & 100 & 100 \\
\hline $\mathrm{ACN}^{\mathrm{AG}}$ & 94 & 67 \\
\hline CpI1 & 89 & 67 \\
\hline 32-27(MpI1) & 72 & 78 \\
\hline 32-44(AirI1) & 72 & 81 \\
\hline AvcI1 & 67 & 78 \\
\hline 32-30(AirI2) & 27 & 70 \\
\hline $\mathrm{G} 2$ & 36 & 59 \\
\hline D11 & 28 & 59 \\
\hline
\end{tabular}

${ }^{a}$ Data from reference 2 .

${ }^{b}$ As determined by using the $S_{\mathrm{SM}}$. isolated from Casuarina glauca and Casuarina equisetifolia, respectively, growing on the banks of the same river, were 93\% related (Fig. 4). In contrast, strains $32-83$ and $32-85$, which were isolated from the same Alnus rugosa plant growing in Massachusetts, clustered at a level of only $78 \%$ (data not shown).

Two mutants of strain $32-27$, strain $4-\mathrm{D}(+)$, which was produced by near-UV irradiation $(366 \mathrm{~nm})$ in the presence of 8-methoxypsoralen, and strain 8-120, which was produced by treatment with $N$-nitro- $N^{\prime}$-nitrosoguanidine, clustered with the parent at a similarity level of $82 \%$ (Fig. 6). A

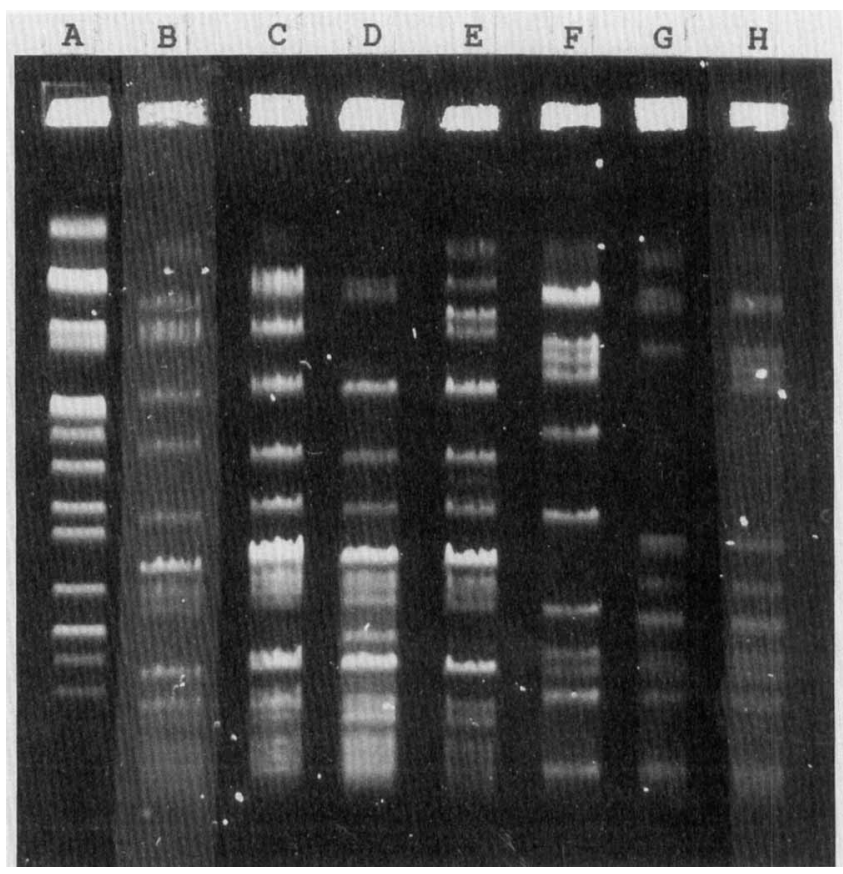

FIG. 4. Pulsed-field gel of the DraI-restricted DNAs of Frankia isolates obtained from members of the Casuarinaceae. Lane A, $S$. cerevisiae standard (see the legend to Fig. 2 for the sizes of the chromosomes); lane $\mathrm{B}$, strain $\mathrm{CgI1}$; lane $\mathrm{C}$, strain CeI5; lane D, strain CeI5SS1; lane E, strain CeI5SS2; lane F, strain R43E2; lane G, strain R43Er-2; lane H, strain R43 (parent). See text. 


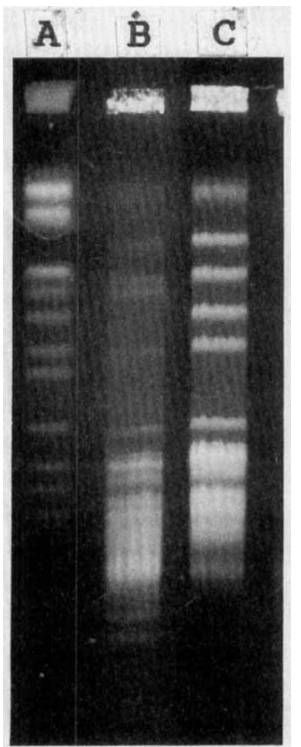

FIG. 5. Pulsed-field gel of Frankia coisolates obtained from Myrica pensylvanica. Lane A, S. cerevisiae standard (see the legend to Fig. 2 for the sizes of the chromosomes); lane B, strain 32-63; lane C, strain 32-74.

spontaneous mutant of strain $\mathrm{R} 43$, strain $\mathrm{R} 43 \mathrm{~A}_{2}$, whose phenotypic behavior has been studied extensively (29), was identical to its parent in its LFRFA patterns.

\section{DISCUSSION}

In this study our aim was to cast some light on the problem of species definition in the genus Frankia. Because of the evolutionary constraints that the symbiotic state undoubtedly imposes, we felt that groups that could be equated with species might be delineated. We also felt that in organisms that have DNAs with such high guanine-plus-cytosine contents (4), the AT-rich sequences must have substantial significance for the organisms. Using DraI, a restriction enzyme that has a TTT'AAA recognition site, we generated DNA digests which contained large fragments (200 to 1,000 kb) that were separable by using pulsed-field electrophoresis. Using this technique, we found that each strain produces a DNA fragment "fingerprint" that is characteristic of the strain. This was also the result that was obtained by other workers who used restriction enzymes that yielded many smaller fragments $(3,13,16,19)$. However, like Bloom et al. (13), we found that our organisms tended to fall into groups, and like Dobritsa and Stupar (20), we found that some coisolates differed very slightly in their patterns. In studies of other bacteria, species-specific restriction patterns have been found for high-molecular-weight fragments of Brucella DNA (1), Mycobacterium tuberculosis DNA (37), and DNAs of certain Streptomyces species (11).

Because the number of our Frankia restriction fragments was relatively small, we calculated the sizes of the fragments and subjected them to a numerical analysis. Of the 15 clusters that were identified at the $>75 \%$ similarity level (Fig. 1), 9 were dominated ( 80 to $100 \%$ ) by isolates obtained from Alnus spp. or members of the Myricaceae, 4 were dominated ( 75 to $100 \%$ ) by isolates obtained from members of the Casuarinaceae, and 2 were mixed. Many, but not all, of the strains that were actually infective for Casuarina spp.

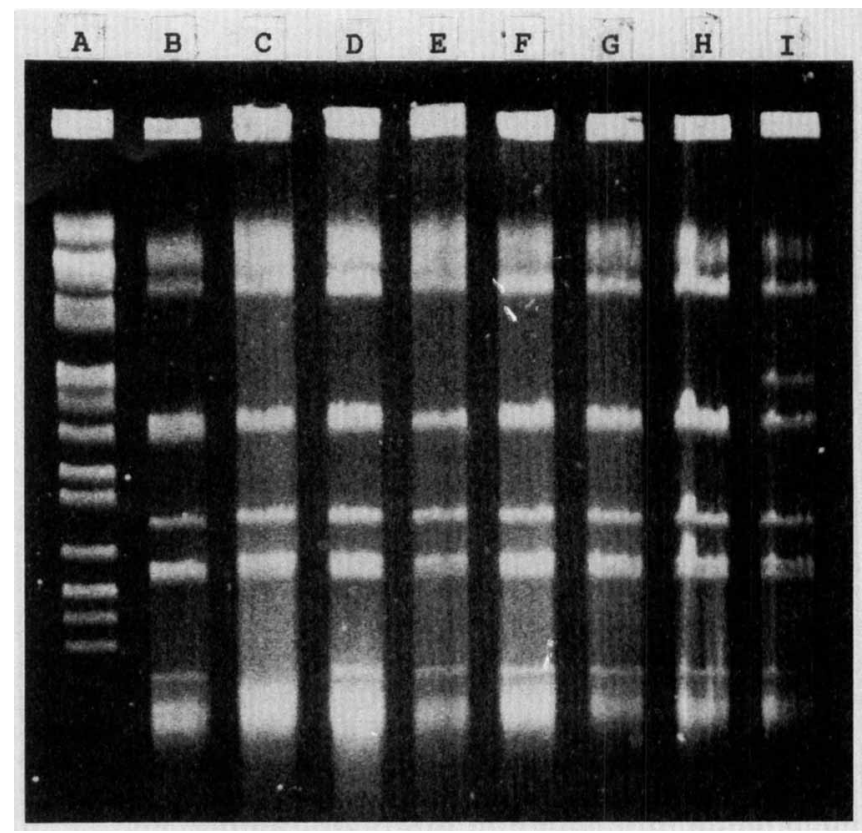

FIG. 6. Pulsed-field gel of mutants and coisolates of Frankia sp. strain 32-27 obtained from Myrica pensylvanica. Lane A, S. cerevisiae standard (see the legend to Fig. 2 for the sizes of the chromosomes); lane $B$, strain 32-27; lane $C$, coisolate 32-21 (note the loss of a small band at $<260 \mathrm{~kb}$ ); lane $\mathrm{D}$, coisolate $32-22$; lane $\mathrm{E}$, mutant 8-120 (note the loss of a doublet at ca. $760 \mathrm{~kb}$ ); lane $\mathrm{F}$, mutant 8-30(+); lane $\mathrm{G}$, mutant 8-30(-); lane $\mathrm{H}$, mutant $4 \mathrm{D}_{2}$; lane $\mathrm{I}$, mutant $4 \mathrm{D}_{2}(+)$ (note the loss of a doublet at ca. $760 \mathrm{~kb}$ and the gain of a fragment at ca. $860 \mathrm{~kb}$ ).

(strains $\mathrm{CeD1}$.82, $\mathrm{CeF1.82,} \mathrm{CcI3}$, and $\mathrm{Cj} 1.82$ ) were found in the major mixed cluster (cluster 4). (As discussed above, many strains isolated from members of the Casuarinaceae and most of the strains isolated from this plant family which we analyzed are not infective for their original hosts.) Thus, our results provide additional evidence which supports the conclusion of Lalonde et al. (24) and Fernandez et al. (21) that many types of analyses (DNA-DNA relatedness, cell polypeptides, isozymes, and fatty acid composition) produce groups of Frankia strains that are consistent with the host plants from which the strains are isolated.

However, there are a number of problems. The first is that the strains which we analyzed differed from the strains that were studied by Lalonde et al., with five exceptions (strains $\mathrm{ACN1}^{\mathrm{AG}}, \mathrm{ARgP}^{\mathrm{AG}}, \mathrm{ArI3}, \mathrm{CpI} 1$, and ACX50h). According to our data and the data of other workers, strains ArI3 and CpI1 are 100\% homologous on the basis of LFRFA results (this paper), cell polypeptide data (23), isozyme data (22), nif sequence data (33), and plasmid data (36). As both of these strains were isolated in the same laboratory, we believe that it is possible that strain ArI3 is a reisolate of strain CpI1. However, strain CpI1, which Lalonde et al. (24) designated the type strain of " $F$. alni subsp. pommerii," did not cluster closely with the 36 Alnus isolates used in our analyses (Fig. 1 ), although it did cluster in fatty acid and isozyme analyses with the Alnus isolates used by Lalonde and his colleagues $(22,35)$. It is possible that if we submitted the strains of Lalonde et al. that were used in the studies discussed above to LFRFA, we would find that they are very similar to strain CpI1; however, on the basis of our results obtained for the few common Alnus isolates analyzed both by us and by 
Lalonde et al., this seems unlikely. For example, both in the isozyme study and in the fatty acid study, the authors placed strain CpI1 in the same group as strain ACX50h (although these strains were actually in two different subgroups). In the same studies, strain CpI1 was clearly segregated from strain $\mathrm{ARgP5}^{\mathrm{AG}}$. In our study, strain CpI1 was very distant from both strain ACX50h (level of similarity, 63\%) and strain $\mathrm{ARgP5}^{\mathrm{AG}}$ (level of similarity, 52\%). In the isozyme study (22), strain ACN1 ${ }^{A G}$ was identical to strain CpI1; in our analyses, these strains exhibited only a very low level of similarity $(48 \%)$. In a study of the conservation of nif sequences (33), strains ACN1 ${ }^{\mathrm{AG}}$ and ArI5 were shown to be $100 \%$ related to strain $\mathrm{CpI} 1$; in our study these strains were related at levels of 48 and $55 \%$, respectively. In the DNA hybridization experiments of Fernandez et al. (21), strains CpI1 and ArI3 were found to be related to a central strain (strain ACON24d) at levels of 81 and $82 \%$, respectively, but no relatedness data for the combination of strains CpI1 and ArI3 were reported. Strain $\mathrm{ARgP5}{ }^{\mathrm{AG}}$ was related at a level of only $2 \%$ to this same central strain, underlining its uniqueness among the Alnus isolates. It is clear that on the basis of the criteria of Lalonde et al., strain CpI1 is closely related to the Alnus isolates which these authors used, whereas in our study, in which we used LFRFA, this strain did not cluster closely with the strains which we examined. The apparent identity of strains CpI1 and ArI3 in all of the studies appears to rule out a difference in the strain CpI1 cultures used by the two groups of workers. It seems possible that LFRFA is more sensitive to differences among strains than the biochemical tests used by Lalonde et al.

In a study of levels of DNA relatedness among 43 Frankia strains, Fernandez et al. (21) proposed nine genomic species on the basis of their results. Although our LFRFA data for a small number of strains common to both studies yielded results that were reasonably congruent with the results of Fernandez et al. (Fig. 3), more LFRFA analyses of the strains of Fernandez et al. will be necessary to determine whether the genomic groups of Fernandez et al. are truly supported by the results of our method. In addition, it is difficult to make a final judgment about the validity of the groups of Fernandez et al., since of the 1,849 possible combinations (43 times 43 ) in their study, they reported test results for only 121 combinations. Thus, the distinctiveness of their various genomic species has not been fully validated by actual hybridization data.

A second problem concerns the fact that in setting up the taxon " $F$. alni subsp. pommerii" (24), according to the International Code of Nomenclature of Bacteria, Lalonde et al. automatically created the taxon $F$. alni subsp. alni (25), but they may not have been aware that they had done so. Of course, $F$. alni subsp. alni would be the type subspecies of the genus. Thus, a type strain should be designated for this taxon. Furthermore, it is clear from studies of other workers and our studies that not enough data have been generated for a common pool of strains to warrant designation of a type strain at this time. We confirmed the finding of Lalonde et al. that strain $\mathrm{ARgP5}^{\mathrm{AG}}$ is distinct from strain $\mathrm{CpI1}$; however, we did not confirm that strain CpI1 is a representative of the Alnus host group in general. We do not believe that our results stem from inadequate sampling; our strains came from more diverse regions than the strains of Lalonde et al. However, strain CpI1 is undoubtedly representative of certain types of isolates obtained from Alnus spp. and members of the Myricaceae and should thus be retained as the type strain of " $F$. alni subsp. pommerii."

The third problem is that some Frankia strains appear to be somewhat mutable (e.g., strains R43, CeI5, and 32-27) when they are assessed by LFRFA, whereas other strains (e.g., strain CcI3) appear to be quite stable. This mutability may be inherent in certain strains. Our observation that the LFRFA patterns for single-spore isolates from a given parent strain (e.g., strains CeSI5, CeI5SS1, and CeI5SS2) can vary from the pattern of the parent may well indicate the basic mechanism for the similar observed variability in some plant-passed reisolates. Mutations in frankiae may be the result of amplifications or deletions of certain sequences, a phenomenon common in other actinomycetes $(12,17)$. They could also be due to base methylation or transposable elements. Nonetheless, mutants and variants of Frankia strains in this study generally clustered closely with their parents (e.g., clusters 7 and 13). However, given that our overall similarity calculations might be termed a snapshot in time, it is possible that repeated passages through various hosts may cause profound changes as assessed by LFRFA, but we have not performed such experiments. However, as our strains included not only recent isolates (e.g., strain R43EU2, which was analyzed immediately following isolation) but also isolates maintained by transfer in vitro for as long as 14 years (strain CpI1), it is significant that our clusters reflect host origin as well as they do. The role of the sequence TTT' AAA in the plant host-endophyte relationship can only be speculated on. However, the compatibility of our findings with those of other workers leads us to propose that LFRFA data should be seriously considered as a valid criterion for grouping Frankia strains into species.

Although we do not feel that we can propose a specific strain as the type strain of $F$. alni subsp. aln $i$ at this time, we believe that such a strain should meet the criteria described below. It should be infective for Alnus sp. and be effective $\left(\right.$ nif $\left.^{+}\right)$. It should be morphologically typical of the genus and have appropriate cell wall chemistry (i.e., type III sensu Lechevalier and Lechevalier [31]) and whole-cell chemistry. In addition, it should be reasonably homologous with a large representative group of strains isolated from Alnus spp. growing in very diverse regions of the world as determined by the following criteria: DNA relatedness data, LFRFA data, isozyme analysis data, fatty acid analysis data, cell sugar analysis data, data on restriction fragment length polymorphisms probed with nifH, and cell polypeptide patterns.

Finally, we urge the various groups invq|ved in studies of Frankia taxonomy to agree on a common pool of strains supplied by a single laboratory as a basis for further work and to try to arrive at a consensus on an appropriate type strain for the genus.

\section{ACKNOWLEDGMENTS}

We thank all of the persons who contributed strains for this study, including Antoon Ackermanns, Vernon Ahmadjian, Dwight Baker, David Benson, Alison Berry, Howard Berg, Ron Bloom, Françoise Horrière, Maurice Lalonde, S. R. Monsour, Philippe Normand, Suzanne Racette, J.-S. Ruan, Luc Simon, J. G. Torrey, Helen Vishniac, and Chris Wheeler. We also thank Hubert A. Lechevalier for his support of this project.

This work was supported by the International Research and Exchange Board and by the Actinomycete Fund of Rutgers University.

\section{REFERENCES}

1. Allardet-Servent, A., G. Bourg, M. Ramuz, M. Pages, M. Bellis, and G. Roizes. 1988. DNA polymorphism in strains of the genus Brucella. J. Bacteriol. 170:4603-4607.

2. An, S. C., W. S. Riggsby, and B. C. Mullin. 1985. Relationships 
of Frankia isolates based on deoxyribonucleic acid homology studies. Int. J. Syst. Bacteriol. 35:140-146.

3. An, S. C., W. S. Riggsby, and B. C. Mullin. 1985. Restriction pattern analysis of genomic DNA of Frankia isolates. Plant Soil 87:43-48.

4. An, S. C., J. W. Wills, W. S. Riggsby, and B. C. Mullin. 1983. Deoxyribonucleic acid base composition of 12 Frankia isolates. Can. J. Bot. 61:2859-2862.

5. Baker, D., and J. G. Torrey. 1980. Characterization of an effective actinorhizal microsymbiont, Frankia sp. AvcIl (Actinomycetales). Can. J. Microbiol. 26:1066-1071.

6. Baker, D. D. 1987. Modification of catalog numbering system for Frankia strains and revision of strain numbers for DDB Frankia collection. Actinomycetes 20:85-88.

7. Baker, D. D. 1987. Relationships among pure-cultured strains of Frankia based on host specificity. Physiol. Plant. 70:245-248.

8. Baker, D. D. (Yale University). 1991. Personal communication.

9. Becking, J. H. 1970. Frankiaceae fam. nov. (Actinomycetales) with one new combination and six new species of the genus Frankia Brunchorst 1886, 174. Int. J. Syst. Bacteriol. 20:201220.

10. Becking, J. H. 1974. Family III. Frankiaceae Becking 1970, 201, p. 701-706. In R. E. Buchanan and N. E. Gibbons (ed.), Bergey's manual of determinative bacteriology. The Williams \& Wilkins Co., Baltimore.

11. Beyazova, M. L., and M. P. Lechevalier. Unpublished data.

12. Birch, A., A. Hausler, and R. Hutter. 1990. Genome rearrangement and genetic instability in Streptomyces spp. J. Bacteriol. 172: $4138-4142$.

13. Bloom, R. A., B. C. Mullin, and R. L. Tate III. 1989. DNA restriction patterns and DNA-DNA solution hybridization studies of Frankia isolates from Myrica pensylvanica (bayberry). Appl. Environ. Microbiol. 55:2155-2160.

14. Burggraaf, A. J. P., and W. A. Shipton. 1983. Studies on the growth of Frankia isolates in relation to infectivity and nitrogen fixation (acetylene reduction). Can. J. Bot. 61:2774-2782.

15. Callaham, D., P. Del Tredici, and J. G. Torrey. 1978. Isolation and cultivation in vitro of the actinomycete causing root nodulation in Comptonia. Science 199:899-902.

16. Crameri, R., G. Hintermann, and R. Hutter. 1983. Deoxyribonucleic acid restriction endonuclease fingerprint characterization of actinomycete strains. Int. J. Syst. Bacteriol. 33:652-655.

17. Cullum, J., J. Altenbuchner, A. W. Birch, F. Flett, K. Kendall, J. Platt, and W. Piendl. 1986. DNA arrangements in Streptomyces, p. 35-44. In G. Szabo, S. Biro, and M. Goodfellow (ed.), Sixth International Symposium on Actinomycetes Biology. Akademiai Kiado, Budapest.

18. Diem, H. G., D. Gauthier, and Y. R. Dommergues. 1982. Isolation of Frankia from nodules of Casuarina equisetifolia. Can. J. Microbiol. 28:526-530.

19. Dobritsa, S. V. 1985. Restriction analysis of the Frankia spp. genome. FEBS Microbiol Lett. 29:123-128.

20. Dobritsa, S. V., and O. S. Stupar. 1989. Genetic heterogeneity among Frankia isolates from root nodules of individual actinorhizal plants. FEMS Microbiol. Lett. 58:287-292.

21. Fernandez, M. P., H. Meugnier, P. A. D. Grimont, and R.
Bardin. 1989. Deoxyribonucleic acid relatedness among members of the genus Frankia. Int. J. Syst. Bacteriol. 39:424-429.

22. Gardes, M., J. Bousquet, and M. Lalonde. 1987. Isozyme variation among 40 Frankia strains. Appl. Environ. Microbiol. 54:1596-1603.

23. Gardes, M., and M. Lalonde. 1987. Identification and subgrouping of Frankia strains using sodium dodecyl sulfate polyacrylamide gel electrophoresis. Physiol. Plant. 70:237-244.

24. Lalonde, M., L. Simon, J. Bousquet, and A. Seguin. 1988. Advances in the taxonomy of Frankia: recognition of species alni and elaeagni and novel subspecies pommerii and vandijkii, p. 671-680. In H. Bothe, F. J. de Bruijn, and W. E. Newton (ed.), Nitrogen fixation: hundred years after. Gustav Fischer Verlag, Stuttgart, Germany.

25. Lapage, S. P., P. H. A. Sneath, E. F. Lessel, V. B. D. Skerman, H. P. R. Seeliger, and W. A. Clark (ed.). 1975. International code of nomenclature of bacteria. 1976 Revision. American Society for Microbiology, Washington, D.C.

26. Lechevalier, M. P. 1983. Cataloging Frankia strains. Can. J. Bot. 61:2964-2967.

27. Lechevalier, M. P. 1984. The taxonomy of the genus Frankia. Plant Soil 78:1-6.

28. Lechevalier, M. P. 1986. Catalog of Frankia strains. Actinomycetes 19:131-162.

29. Lechevalier, M. P., D. P. Labeda, and J.-S. Ruan. 1987. Studies of Frankia sp. LLR 02022 from Casuarina cunninghamiana and its mutant LLR 02023. Physiol. Plant. 70:249-254.

30. Lechevalier, M. P., and H. A. Lechevalier. 1989. Genus Frankia Brunchorst $1886,174^{\mathrm{AL}}$, p. $2410-2417$. In S. T. Williams, M. E. Sharpe, and J. G. Holt (ed.), Bergey's manual of systematic bacteriology, vol. 4. The Williams \& Wilkins Co., Baltimore.

31. Lechevalier, M. P., and H. A. Lechevalier. 1990. Systematics, isolation and culture of Frankia, p. 35-60. In C. R. Schwintzer and J. D. Tjepkema (ed.), The biology of Frankia and actinorhizal plants. Academic Press, San Diego, Calif.

32. Mansour, S. R., A. Dewedar, and J. G. Torrey. 1990. Isolation, culture and behavior of Frankia strain HFP CgI4 from root nodules of Casuarina glauca. Bot. Gaz. 151:490-496.

33. Normand, P., P. Simonet, and R. Bardin. 1988. Conservation of nif sequences in Frankia. Mol. Gen. Genet. 213:238-246.

34. Shi, Y., J. Ruan, J. Zakrzewska-Czerwinska, and M. Mordarski. 1991. DNA homology of some Frankia strains. Actinomycetes II:86-88.

35. Simon, L., S. Jabaji-Hare, J. Bousquet, and M. Lalonde. 1989. Confirmation of Frankia species using cellular fatty acid analysis. Syst. Appl. Microbiol. 11:229-235.

36. Simonet, P., P. Normand, A. Moiroud, and M. Lalonde. 1985. Restriction enzyme digestion patterns of Frankia plasmids. Plant Soil 87:49-60.

37. Smith, C. L. (Columbia University). 1986. Personal communication.

38. Smith, C. L., and C. R. Cantor. 1987. Purification, specific fragmentation and separation of large DNA molecules. Methods Enzymol. 155:449-467.

39. Sneath, P. H. A., and R. R. Sokal. 1973. Numerical taxonomy. W. H. Freeman and Co., San Francisco. 